\title{
SPATIAL SCALE EFFECTS OF SAMPLING ON THE INTERPOLATION OF SPECIES DISTRIBUTION MODELS IN THE SOUTHWESTERN AMAZON ${ }^{1}$
}

Symone Maria de Melo Figueiredo ${ }^{2 *}$, Eduardo Martins Venticinque ${ }^{3}$ and Evandro Orfanó Figueiredo ${ }^{4}$

\footnotetext{
${ }^{1}$ Received on 19.11.2014 accepted for publication on 24.06.2016.

${ }^{2}$ Universidade Federal do Acre, Centro de Ciências Biológicas e da Natureza, Rio Branco, AC - Brasil. E-mail: <symone_ac@yahoo.com.br>.

${ }^{3}$ Universidade Federal do Rio Grande do Norte, Centro de Biociências, Departamento de Biologia, Natal, RN - Brasil. E-mail: <eduardo.venticinque@gmail.com>.

${ }^{4}$ Empresa Brasileira de Pesquisa Agropecuária - Embrapa, Centro de Pesquisa Agroflorestal do Acre -CPAF - Acre, Rio Branco, AC - Brasil. E-mail: <orfano@cpafac.embrapa.br>.

*Corresponding author.
}

\begin{abstract}
Knowledge of the geographical distribution of timber tree species in the Amazon is still scarce. This is especially true at the local level, thereby limiting natural resource management actions. Forest inventories are key sources of information on the occurrence of such species. However, areas with approved forest management plans are mostly located near access roads and the main industrial centers. The present study aimed to assess the spatial scale effects of forest inventories used as sources of occurrence data in the interpolation of potential species distribution models. The occurrence data of a group of six forest tree species were divided into four geographical areas during the modeling process. Several sampling schemes were then tested applying the maximum entropy algorithm, using the following predictor variables: elevation, slope, exposure, normalized difference vegetation index (NDVI) and height above the nearest drainage (HAND). The results revealed that using occurrence data from only one geographical area with unique environmental characteristics increased both model overfitting to input data and omission error rates. The use of a diagonal systematic sampling scheme and lower threshold values led to improved model performance. Forest inventories may be used to predict areas with a high probability of species occurrence, provided they are located in forest management plan regions representative of the environmental range of the model projection area.
\end{abstract}

Keywords: MaxEnt; NDVI; HAND.

\section{EFEITO DA ESCALA ESPACIAL DE AMOSTRAGEM NA INTERPOLAÇÃO DE MODELOS DE DISTRIBUIÇÃO DE ESPÉCIES NA AMAZÔNIA SUL- OCIDENTAL}

\begin{abstract}
RESUMO - O conhecimento sobre a distribuição geográfica de espécies florestais madeireira na Amazônia, principalmente em escala local, ainda é pequeno, limitando ações de gestão dos recursos naturais. Os inventários florestais são fonte de informações importantes sobre a ocorrência dessas espécies, porém a localização de áreas com planos de manejo licenciados estão concentrados em regiões próximas as vias de acesso e aos principais pólos de industrialização. O objetivo desse estudo é avaliar o efeito da escala espacial dos inventários florestais como fonte de dados de ocorrências aplicados a interpolação dos modelos de distribuição potencial de espécies. Na modelagem, os dados de ocorrência de um grupo de seis espécies florestais foram divididos em quatro regiões geográficas e testados vários esquemas de amostragem com aplicação do algoritmo de máxima entropia, usando como variáveis preditoras: altitude, declividade, orientação do terreno, índice de vegetação por diferença normalizada (NDVI) e distância vertical à drenagem mais próxima (HAND). A utilização de dados de ocorrência de apenas uma região geográfica com características ambientais singulares aumentou tanto o sobreajustamento dos modelos aos dados de entrada como os erros de omissão. O esquema
\end{abstract}


de amostragem em diagonal e o uso de valores mais baixos de limiar influenciaram na melhoria do desempenho dos modelos. Os inventários florestais podem ser utilizados para predizer regiões com alta probabilidade de ocorrência de espécies, desde que estejam localizados em planos de manejo florestal que representem a amplitude ambiental da área de projeção dos modelos.

Palavras-chave: Maxent; NDVI; HAND.

\section{INTRODUCTION}

Species distribution models(SDM) correlate the distribution of species occurrence points at known sites with a multivariate environmental dataset. Using computer algorithms, these can be used to predict the points in geographic space at which species occurrence is likely (PHILLIPS et al., 2006; PEARSON et al., 2007). All SDMs are affected by the spatial scale of predictive environmental variables and the location and distribution of species presence records in the landscape (ELITH; LEATHWICK, 2009; RÖDDER; LÖTTERS, 2010).

Studies evaluating the predictability of SDM in regions without species presence or absence data remain scarce. These are usually aimed at assessing the effects of climate change on potential species distribution or invasion potential and expansion of exotic species (VANREUSEL et al., 2007; TOWNSEND PETERSON et al., 2007; PHILLIPS, 2008; RÖDDER; LÖTTERS, 2010). The performance of SDMs is most commonly evaluated by testing the area in which the model was developed (VANREUSEL et al., 2007). This is usually because the number of species occurrence data is small (KUMAR; STOHLGREN, 2009). Thus, assessing the effectiveness of such models in independent areas (VANREUSEL et al., 2007; GRAY et al., 2009) becomes increasingly more important in conservation studies (HEIKKINEN et al., 2012).

Considering the limited availability of data and information on forest tree species in the tropics, especially the Amazon, forest inventories conducted according to procedures of the Digital Model of Forest Exploitation - Modeflora (FIGUEIREDO et al., 2007) are an alternative method for increasing the knowledge of these species and may be used as a data source in studies involving SDMs.

In the state of Acre, Brazil, private forest management plans are commonly located in areas near access roads and main industrial centers. Within this state, nature conservation units and indigenous lands occupy $46 \%$ of the territory (ACRE, 2007). These are comprised mostly of long corridors with minimum forest surveys. Of interest to this study were the effects of the geographical distribution of forest inventories on the performance of SDMs. We aimed, therefore, to assess the effects of geographical distribution and number of species occurrences on the sampling of SDM using data collected from forest inventories. This was at a local scale in order to make predictions in independent areas within a specific geographical region.

\section{MATERIALAND METHODS}

\section{1.Study area}

The studies were conducted in eastern Acre, Brazil, where four geographical areas were defined using parallels and meridians separated by one degree as a reference (Figure 1). The total area was $48,460 \mathrm{~km}^{2}$.

\subsection{Forest tree species data}

Modeling was performed using six forest tree species (Table 1), which were selected using the following criteria: occurrence in all specific geographical areas and matching common and scientific species names. Collection of botanical material was performed by herborization and confirmation of the scientific species name. The dried specimens were deposited in the UFACPZ herbarium of the Zoobotanical Park at the Federal University of Acre (Universidade Federal do Acre - UFAC).

The occurrence records of the timber tree species of interest were derived from forest censuses in areas with a Sustainable Forest Management Plan (SFMP), which was approved by the state environmental agency.

Forest inventories were conducted using the techniques recommended by the Digital Model of Forest Exploitation (Modeflora). Modeflora is asset of procedures aimed at precision tropical forest management using methods, such as high-sensitivity GPS and Geographic Information System(GIS), in forest planning. This model was developed by the Brazilian Agricultural Research Corporation (Empresa Brasileira de Pesquisa 


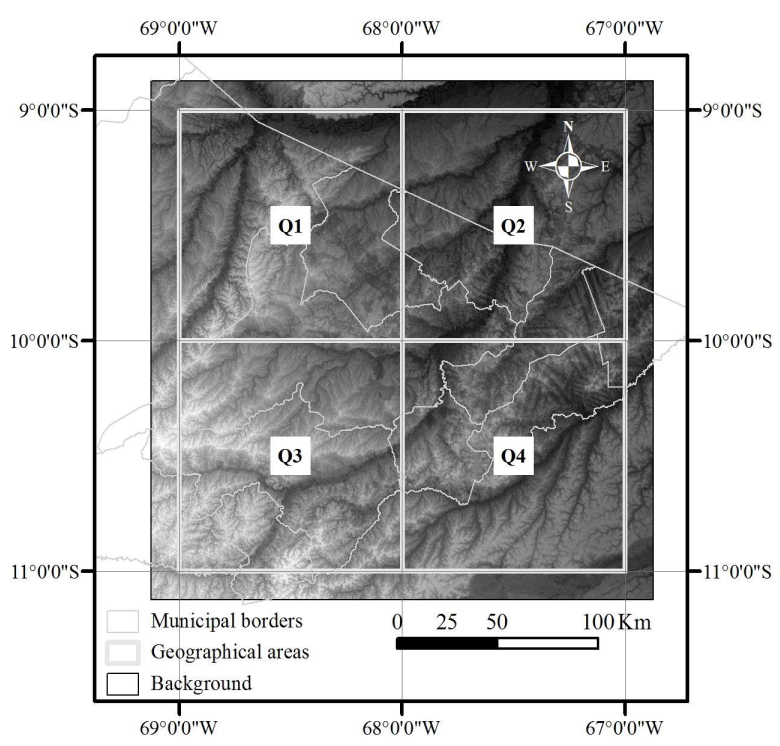

Figure 1 - The study area was divided into four geographical areas or quadrants (Q1, Q2, Q3, and Q4). This figure shows the gray scale elevation map used in modeling.

Figura 1-Os retângulos ( $Q 1, Q 2, Q 3$ e $Q 4)$ representam a divisão da área de estudo em regiões geográficas ou quadrantes. A figura em tons de cinza mostra a variável altitude utilizada na modelagem.

Agropecuária - Embrapa) Acre and Embrapa Forestry (Embrapa Floresta) (FIGUEIREDO et al., 2007). The database was provided by Embrapa Acre and by the Acre Environmental Institute (Instituto de Meio Ambiente do Acre - IMAC).

\subsection{Environmental variables}

The following predictive environmental variables were used: elevation, slope, aspect, Normalized Difference Vegetation Index (NDVI) and Height Above the Nearest Drainage (HAND). Topographic variables were collected from Shuttle Radar Topographic Mission (SRTM) data at $90 \mathrm{~m}$ resolution. The NDVI was assessed using Landsat
Thematic Mapper (TM) images of the dry season of 2011 (before exploiting the managed areas), which show little cloud cover. All HAND data were processed according to the methodology reported by Rennó et al. (2008). These data are indirectly related to the water table depth, which, in turn, indicates the soil water availability. Such variables may be used as predictive measures in species distribution models (FIGUEIREDO et al., 2015) because species occurrence may be affected by its adaptive characteristics and habitat preferences. This is regardless of whether or not it is in wetter or well drained soil areas.

\subsection{Model construction}

The maximum entropy algorithm (MaxEnt), which is recognized as an efficient method and often used in biodiversity studies (ARANDA; LOBO, 2011; WARREN; SEIFERT, 2011), was employed to construct the species potential distribution model. MaxEnt estimates the probability of habitat suitability in which the species may occur. It calculates the maximum entropy probability distribution (closest to uniform) subjected to a set of constraints, in which the expected values of each environmental variable should correspond to their observed sample means (PHILLIPS et al., 2006; PEARSON et al., 2007; ELITH et al., 2011). All models were run with Maximum Entropy Modeling of Species Geographic v. 3.3.3k (<www.cs.princeton.edu/ schapire/ $\operatorname{maxent} />$ ).

Only environmental variables with a Pearson correlation coefficient lower than 0.7 were included in the MaxEnt algorithm application. This was to avoid highly correlated variables.

The data-partitioning scheme was tested in four different geographical management areas, termed quadrants (Figure 1), to assess the spatial scale effects. Data collected from forest inventories in one or more geographical areas were used to perform the interpolation of the other areas to evaluate the generality of using

Table 1 - Forest species selected for modeling.

Tabela 1 - Relação das espécies florestais selecionadas para a modelagem.

\begin{tabular}{clcc}
\hline Id & Scientific name & Family & Total no. of occurrences \\
\hline 1 & Apuleia leiocarpa (Vogel) J.F.Macbr. & Fabaceae & 960 \\
2 & Aspidosperma parvifolium A.DC. & Apocynaceae & 640 \\
3 & Astronium lecointei Ducke. & Anacardiaceae & 420 \\
4 & Castilla ulei Warb. & Moraceae & 1.080 \\
5 & Ceiba pentandra (L.) Gaertn. & Malvaceae & 560 \\
6 & Clarisia racemosa Ruiz \& Pav & Moraceae & 560 \\
\hline
\end{tabular}


a model constructed with data from one management area to predict the distribution in another geographical area. Records near to more than one quadrant were excluded from occurrence data to minimize the geographical dependence between samples. The same number of occurrences was then randomly selected per species from each quadrant. Thus, the higher the number of quadrants used for training samples or algorithm calibration, the higher the number of occurrence records used in modeling.

Three partitioning schemes of training samples covering $25 \%, 50 \%$, and $75 \%$ of the study area were used to test the geographical distribution effects of forest inventories on model performance. Occurrences in one (25\% area), two (50\% area) and three ( $75 \%$ area) quadrants were used in all possible combinations. This represented different sampling efforts, for the algorithm training sample, in partitioning schemes 1, 2, and 3, respectively.

\subsection{Model evaluation}

The values of Area Under the Curve (AUC) and the omission error rates of the individual models, which are considered a key AUC auxiliary measure by Jiménez Valverde et al. (2008) and Lobo et al., 2008, were analyzed to assess sampling scheme effects on model performance.

The AUC is often used because it is an overall performance measure independent of cutoffs (FIELDING; BELL, 1997). The analysis of external test sample AUC, and its difference from the training sample AUC, termed AUCdifference (AUCdif = AUCtraining - AUCtest), were calculated. Such a difference is used to assess model overûtting to the data (RÖDDER; LÖTTERSE, 2010; RADOSAVLJEVIC; ANDERSON, 2013).

A threshold or cutoff must be used to calculate the omission error rate of the model. Its choice should maximize the agreement between the observed and predicted species distribution and meet the research goals (LIU et al., 2005). The conversion of continuous probability maps into binary maps of possible species presence (1) or absence (0) was performed using a threshold (value).

The following effects of both thresholds on the omission error rates of the models were tested: the lowest probability value associated with the training dataset of the algorithm, or Minimum Training Presence (MTP) logistic threshold, and the lowest probability

Revista Árvore, Viçosa-MG, v.40, n.4, p.617-625, 2016 value associated with training data excluding the $10 \%$ lowest predicted values, or 10 Percentile Training Presence (10PTP) logistic threshold. Both thresholds are commonly applied in studies involving SDM (PEARSON et al., 2007; KUMAR; STOHLGREN, 2009;ARANDA; LOBO, 2011).

A Kruskal-Wallis (K), Mann-Whitney (U) and paired T test ( $\mathrm{t})$ were used to assess the significance $(a=0.05)$ of the variation of the values of AUC, omission error rate of the models resulting from different data sampling schemes, experimental design, and threshold selection.

\section{RESULTS}

Exploratory analysis of occurrence data revealed the environmental gradient of the variables elevation and NDVI occupied by the species in the forest management plans, according to the sampling quadrants (Figure 1). The elevation ranged from 145 to $285 \mathrm{~m}$, while the NDVI values ranged from 0.2 to 0.7 for the occurrences in quadrants Q1, Q2, Q3 and Q4 (Figure 2).

The gradient of the NDVI associated with species occurrence was similar in all sampling quadrants, as the management plans are located in forest areas. Variation results from the forest type. NDVI values in open forests with bamboo are lower than in dense forests.

The greatest elevation range occurred in quadrant $\mathrm{Q} 1$, with spot elevation ranging from 159 to $267 \mathrm{~m}$. Occurrences located in quadrant Q2 were concentrated in an area closer to the Acre and Andirá rivers and their tributaries. This was the lowest spot elevation (145 to $201 \mathrm{~m}$ ) of the study area. Species occurrence sites located in quadrant Q3 exhibited the highest spot elevation, reaching $285 \mathrm{~m}$. Thus, this area has different environments from other forest management areas.

The test AUC value ranged from 0.51 to 0.71 . This was based on the one-quadrant scheme for training. The AUC ranged from 0.56 to 0.70 and from 0.48 to 0.74 when using two and three quadrants, respectively. Figure 3 shows the results of the statistical test of model performance according to the number of occurrences or number of quadrants used in modeling.

The AUCdifference averaged 0.29, 0.20, and 0.16 when using occurrences located in one, two, and three quadrants in model construction, respectively. Greater differences between AUCtest and AUCtraining resulted in greater model overfitting to input data. 

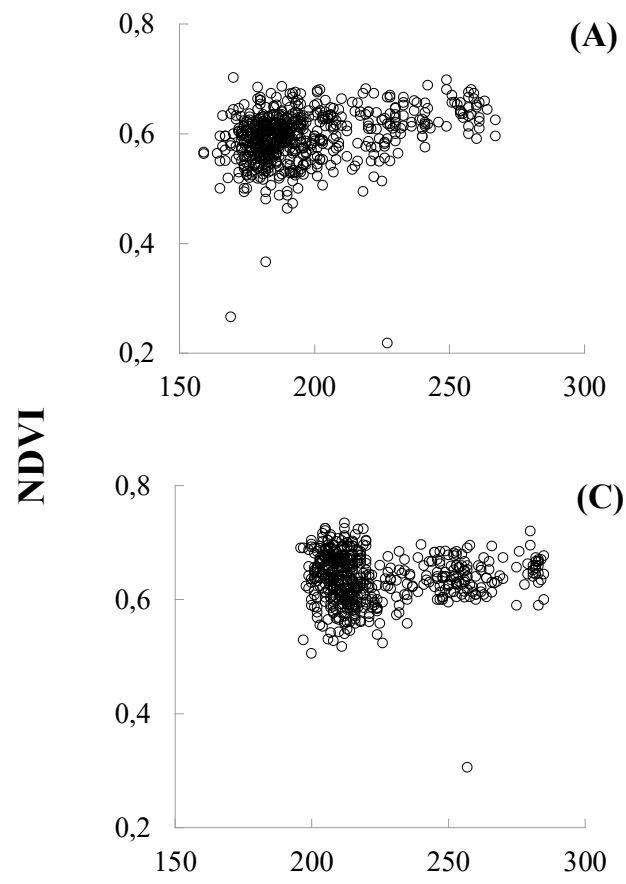

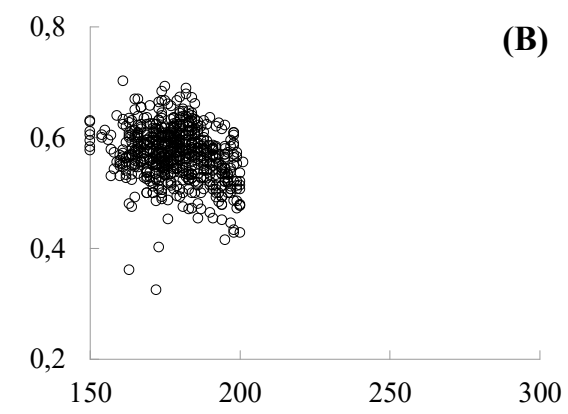

(A)

C)

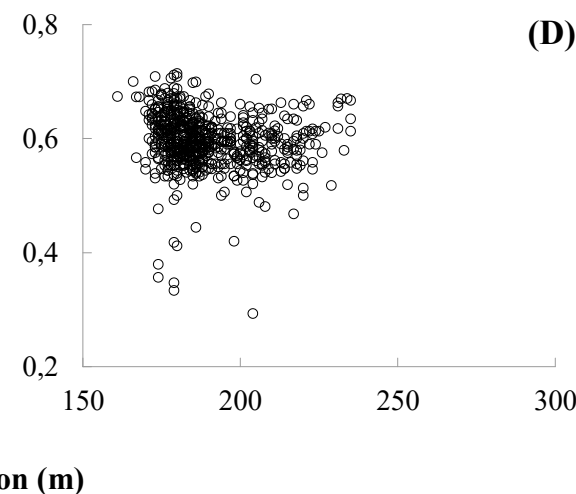

Figure 2 - Environmental gradient of the variables elevation and normalized difference vegetation index (NDVI) associated with occurrence sites of the forest species, according to the partitioning scheme of the data into quadrants: $\mathrm{A}(\mathrm{Q} 1), \mathrm{B}(\mathrm{Q} 2), \mathrm{C}(\mathrm{Q} 3)$ and $\mathrm{D}(\mathrm{Q} 4)$.

Figura 2 - Gradiente ambiental das variáveis altitude e indice de vegetação por diferença normalizada (NDVI) associado aos locais de ocorrência das espécies florestais, de acordo como o esquema de particionamento de dados em quadrantes: $A(Q 1), B(Q 2), C(Q 3)$ e $D(Q 4)$.

The omission error rates of the models using MTP threshold were, on average, four times lower than using the 10PTP threshold (paired $t$ test, $p<0.001$, Figure 4 ). Using 10PTP generated a map that underestimated the predicted distribution area of the study species, with a $47 \%$ mean error.

Using the MTP threshold, $64 \%$ of the models exhibited omission error rates of up to $10 \%$. The omission error rates averaged 3\% when applying the sampling scheme using three quadrants. These were significantly different from the schemes with one or two quadrants(Figure 4A).

\section{DISCUSSION}

Model performance was strongly affected by the geographical distribution of occurrence data in areas where the environmental gradient was different from that of the forest management plan areas in which the models were interpolated. This was revealed when using the records of species found in quadrant Q3. The model generated using occurrence data from this quadrant had the highest omission error rate, which was significantly affected by the means of environmental variables associated with species occurrence.

The results from the models constructed using occurrence records, either for training or testing, and located in a narrow geographical area with a unique environmental gradient, adversely affected the spatial prediction of species distribution. This was because any prediction calculation for other sites was based on the environmental space occupied by the species instead of geographical space (ELITH; LEATHWICK, 2009).

Such negative effects were minimized when using quadrants in a diagonal systematic sampling scheme. Models using this approach produced a mean AUC of

Revista Árvore, Viçosa-MG, v.40, n.4, p.617-625, 2016 

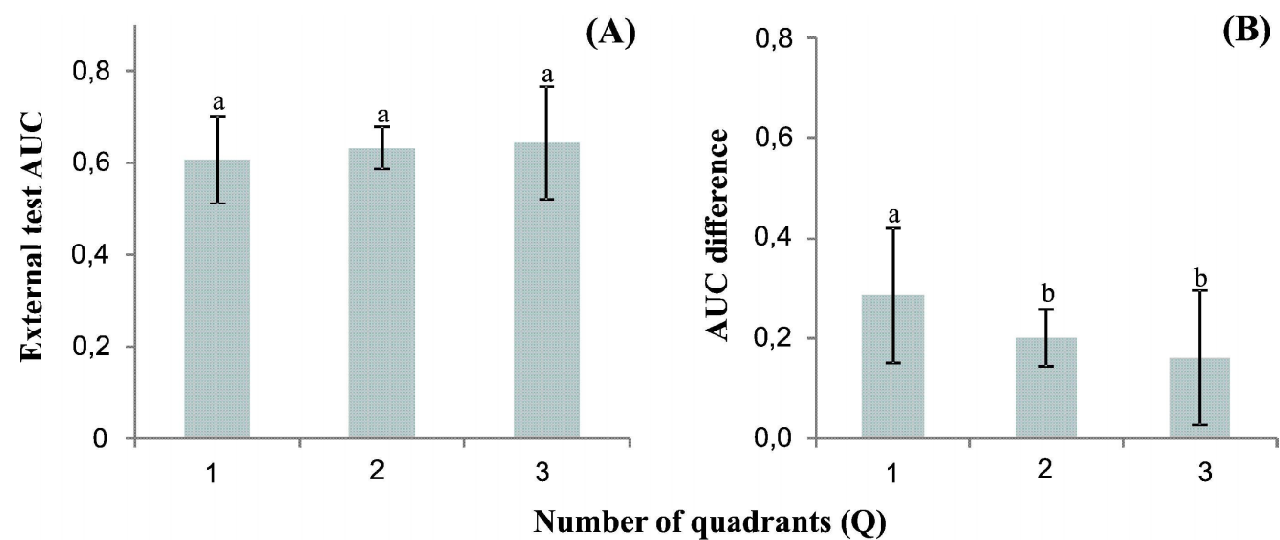

Figure 3 - Mean area under the curve - AUC (A) and AUC difference (B) between models. Vertical lines indicate the standard deviation from the mean. Columns followed by the same letter are not significantly different from each other at $5 \%$ probability, according to the Mann-Whitney U test.

Figura 3 - Média da área sob a curva - AUC (A) e AUC diferença (B) dos modelos. Linhas verticais indicam o desvio padrão da média. Colunas seguidas por uma mesma letra não diferem entre si ao nível de $5 \%$ de probabilidade pelo teste U de Mann-Whitney.
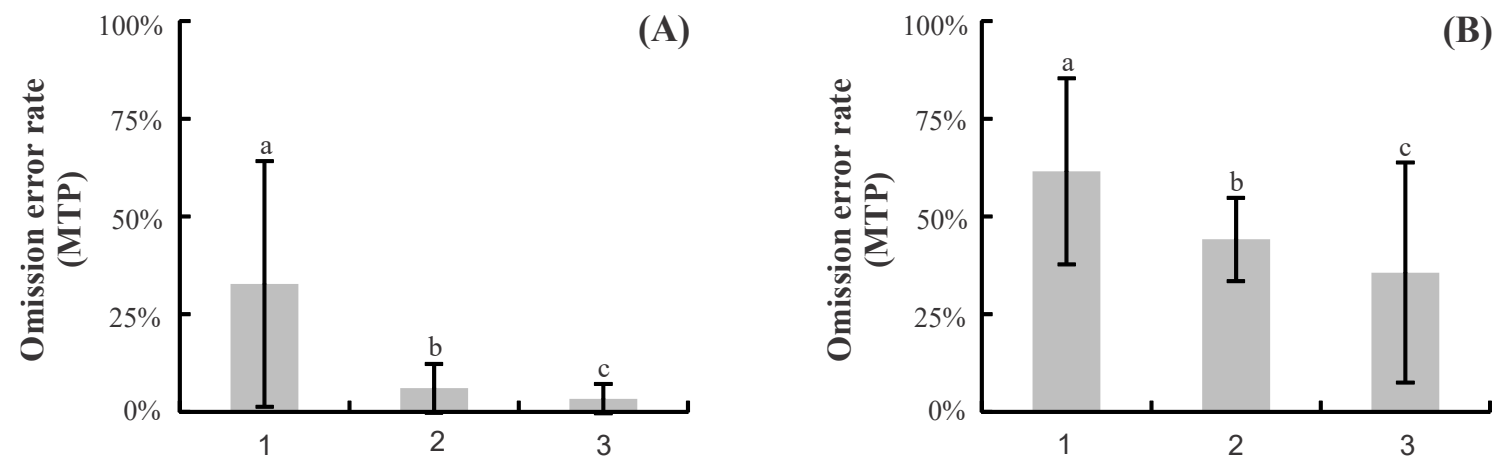

Number of quadrants $(\mathbf{Q})$

Figure 4 - Mean omission error rate applying the Minimum Training Presence-MTP (A) and 10 Percentile Training Presence-10PTP (B) thresholds. Vertical lines indicate the standard deviation from the mean. Columns followed by the same letter are not significantly different from each other at $5 \%$ probability, according to the $\mathrm{T}$ test.

Figura 4-Média da taxa de omissão aplicando o limiar Minimum Training Presence-MTP (A) e 10 Percentile Training Presence-10PTP (B). Linhas verticais indicam o desvio padrão da média. Colunas seguidas por uma mesma letra não diferem entre si ao nível de $5 \%$ de probabilidade pelo teste T.

0.7 and $2 \%$ omission error rate. This was due to the environmental restrictions applied to the models, which had a wider range of environmental characteristics. These results are consistent with the findings of Townsend Peterson et al. (2007), who also tested the diagonal systematic sampling scheme and obtained models with AUC, when applying MaxEnt, ranging from 0.6 to 0.9 .

Models using three quadrants in the training sample performed significantly better than the other models evaluated. The model using the occurrences in quadrant Q1 for algorithm training performed similarly to a model with three quadrants. Given that the representativeness of environmental variables associated with occurrences in this quadrant, it shows that using forest inventory data from a geographical area may help predict potential forest management areas in other regions.

The AUC value tended to increase with the number of species occurrences of the MaxEnt training sample, albeit with a non-significant difference. Anderson 
and Gonzalez (2011) also reported there was no improvement in model performance associated with an increased number of species occurrences.

Conversely, we observed an inverse and significant relationship between the number of quadrants and the difference between the test and training AUC. That is, the higher the number of quadrants used in constructing the model, the smaller the AUCdifference was, thereby minimizing the effects of sampling bias. Townsend Peterson et al. (2007) and Kramer-Schadt et al. (2013) reported similar results.

A higher omission error rate was associated with the 10PTP threshold. This occurred when comparing both thresholds tested for the transformation of the continuous probability map into a binary map. This was also reported by Pearson et al. (2007) and Radosavljevic and Anderson (2013).

The omission error rate of the models varied significantly with the number of occurrences used in modeling, regardless of threshold (MTP or 10PTP). The decrease in the number of occurrences increased the omission error rates of the models, albeit without significantly affecting the AUC, which was also reported by Pearson et al. (2007) and Feeley and Silman (2011). Using the highest possible number of training data to reduce the omission error rates of the models is, therefore, highly recommended.

Thus, we emphasize the importance of obtaining a high number of occurrence data to more accurately map potential species distribution areas. The number of data are not, however, the only issue. The results reported herein indicate the existence of an environmental bias effect on model predictability, as Phillips (2008) and Aranda and Lobo (2011) also noted in their studies.

\section{CONCLUSIONS}

Species distribution models are strongly affected by the limited range of occurrence observed in geographical areas with unique environmental characteristics of the landscape in which they are projected, thereby resulting in maps that underestimate the area occupied by the species.

Using a higher value of 10PTP threshold to convert the probability map into a binary map, and a lower number of training occurrence data, also increased the omission error rate of the models.
Environmentally suitable areas with low omission error rates, and the likely presence of the forest tree species of interest, may be determined using presence records from forest inventories that cover geographical areas representative of the environmental gradient range of the model projection area.

\section{ACKNOWLEDGEMENTS}

The authors thank the Coordination for the Improvement of Higher Education Personnel (Coordenação de Aperfeiçoamento de Pessoal de Nível Superior - Capes) for granting the scholarship to the first author. The National Council for Scientific and Technological Development (Conselho Nacional de Desenvolvimento Científico e Tecnológico - CNPq) is thanked for awarding are search productivity scholarship (Process: 309458/2013-7) to the second author. We would also like to acknowledge the Acre Technology Foundation (Fundação de Tecnologia do Acre) and the Acre Environmental Institute (Instituto de Meio Ambiente do Acre) for funding and for their collaboration in this study, respectively.

\section{REFERENCES}

ACRE. Governo do Estado do Acre. Programa Estadual de Zoneamento Ecológico-Econômico do Estado do Acre. Zoneamento Ecológico-Econômico do Acre Fase II - Documento Síntese - Escala 1:250.000. Rio Branco: SEMA, 2007. 356p.

ANDERSON, R.P.; GONZALEZ JR, I. Speciesspecific tuning increases robustness to sampling bias in models of species distributions: an implementation with Maxent. Ecological Modelling, v.222, n.15, p.2796$2811,2011$.

ARANDA, S.C.; LOBO, J.M. How well does presence only based species distribution modelling predict assemblage diversity? A case study of the Tenerife flora. Ecography, v.34, n.1, p.31-38, 2011.

ELITH, J.; LEATHWICK, J.R. Species distribution models: ecological explanation and prediction across space and time. Annual Review of Ecology, Evolution, and Systematics, v.40, n.1, p.677, 2009.

Revista Árvore, Viçosa-MG, v.40, n.4, p.617-625, 2016 
ELITH, J.; PHILLIPS, S.J.; HASTIE, T.; DUDÍK, M.; CHEE, Y.E.; YATES, C.J. A statistical explanation of MaxEnt for ecologists. Diversity and Distributions, v.17, n.1, p.43-57, 2011.

FEELEY, K.J.; SILMAN, M.R. Keep collecting: accurate species distribution modelling requires more collections than previously thought.

Diversity and Distributions, v. 17, n.6, p.1132-1140, 2011.

FIELDING, A.H.; BELL, J.F. A review of methods for the assessment of prediction errors in conservation presence/absence models.

Environmental Conservation, v.24, n.1, p.38-49, 1997.

FIGUEIREDO, E.O.; BRAZ, E.M.; d'OLIVEIRA, M.V.N. Manejo de precisão em florestas tropicais: modelo digital de exploração florestal. Rio Branco: Embrapa Acre, 2007. 183p.

FIGUEIREDO, S.M.M.; VENTICINQUE, E.M.; FIGUEIREDO, E.O.; FERREIRA, E.J.L. Predição da distribuição de espécies florestais usando variáveis topográficas e de índice de vegetação no leste do Acre, Brasil. Acta Amazonica, v.45, n.2, p.167-174, 2015.

GRAY, T.N.; BOREY, R.O.; HOUT, S.K.; CHAMNAN, H.; COLLAR, N.; DOLMAN, P. M. Generality of models that predict the distribution of species: conservation activity and reduction of model transferability for a threatened bustard.

Conservation Biology, v.23, n.2, p.433-439, 2009.

HEIKKINEN, R.K.; MARMION, M.; LUOTO, M. Does the interpolation accuracy of species distribution models come at the expense of transferability? Ecography, v.35, n.3, p.276-288, 2012.

JIMÉNEZ VALVERDE, A.; LOBO, J.M.; HORTAL, J. Not as good as they seem: the importance of concepts in species distribution modelling.

Diversity and Distributions, v.14, n.6, p.885-890, 2008 .

KRAMER-SCHADT, S.; NIEDBALLA, J.; PILGRIM, J.D.; SCHRÖDER, B.; LINDENBORN, J.; REINFELDER, V.; WILTING, A. The importance of correcting for sampling bias in MaxEnt species

Revista Árvore, Viçosa-MG, v.40, n.4, p.617-625, 2016 distribution models. Diversity and

Distributions, v.19, n.11, p.1366-1379, 2013.

KUMAR, S.; STOHLGREN, T.J. Maxent modeling for predicting suitable habitat for threatened and endangered tree Canacomyrica monticola in New Caledonia. Journal of Ecology and the Natural Environment, v. 1, n.4, p.9498, 2009.

LIU, C.; BERRY, P.M.; DAWSON, T.P.; PEARSON, R.G. Selecting thresholds of occurrence in the prediction of species distributions.

Ecography, v.28, n.3, p.385-393, 2005.

LOBO, J.M.; JIMÉNEZ VALVERDE, A.; REAL, R. AUC: a misleading measure of the performance of predictive distribution models. Global Ecology and Biogeography, v.17, n.2, p.145-151, 2008 .

PEARSON, R.G.; RAXWORTHY, C.J.; NAKAMURA, M.; TOWNSEND PETERSON, A. Predicting species distributions from small numbers of occurrence records: a test case using cryptic geckos in Madagascar. Journal of Biogeography, v.34, n.1, p.102-117, 2007.

PHILLIPS, S.J.; ANDERSON, R.P.; SCHAPIRE, R.E. Maximum entropy modeling of species geographic distributions. Ecological Modelling, v. 190, n.3, p.231-259, 2006.

PHILLIPS, S.J. Transferability, sample selection bias and background data in presence only modelling: a response to Peterson et al.(2007). Ecography, v.31, n.2, p.272-278, 2008.

RADOSAVLJEVIC, A.; ANDERSON, R.P. Making better Maxent models of species distributions: complexity, overfitting and evaluation. Journal of Biogeography, v.41, n.4, p.629-643, 2014.

RENNÓ, C.D.; NOBRE, A.D.; CUARTAS, L.A.; SOARES, J.V.; HODNETT, M.G.; TOMASELLA, J.; WATERLOO, M.J. HAND, a new terrain descriptor using SRTM-DEM: Mapping terrafirme rainforest environments in Amazonia. Remote Sensing of Environment, v.112, n.9, p.3469-3481, 2008.

RÖDDER, D.; LÖTTERS, S. Explanative power of variables used in species distribution modelling: 
an issue of general model transferability or niche shift in the invasive Greenhouse frog

(Eleutherodactylus planirostris).

Naturwissenschaften, v.97, n.9, p.781-796, 2010 .

TOWNSEND PETERSON, A.; PAPES, M.;

EATON, M. Transferability and model evaluation in ecological niche modeling: a comparison of GARP and Maxent. Ecography, v.30, n.4, p.550-560, 2007.
VANREUSEL, W.; MAES, D.; VAN DYCK, H. Transferability of species distribution models: a functional habitat approach for two regionally threatened butterflies. Conservation Biology, v.21, n.1, p.201-212, 2007.

WARREN, D.L.; SEIFERT, S.N. Ecological niche modeling in Maxent: the importance of model complexity and the performance of model selection criteria. Ecological Applications, v. 21, n.2, p.335-342, 2011. 